\title{
NOSOCOMIAL INFECTIONS IN HUMAN IMMUNODEFICIENCY VIRUS TYPE 1 (HIV-1) INFECTED AND AIDS PATIENTS: MAJOR MICROORGANISMS AND IMMUNOLOGICAL PROFILE
}

\author{
Panis, C. ${ }^{1}$; Matsuo, T. ${ }^{2}$; Reiche, E.M.V. ${ }^{1}$ \\ ${ }^{1}$ Departamento de Patologia, Análises Clínicas e Toxicológicas, Centro de Ciências da Saúde, Universidade Estadual de Londrina, \\ Londrina, PR, Brasil; ${ }^{2}$ Departamento de Estatística, Centro de Ciências Exatas, Universidade de Londrina, Londrina, PR, Brasil.
}

Submitted: June 29, 2007; Returned to authors for corrections: September 22, 2007; Approved: November 05, 2008.

\begin{abstract}
Antiretroviral therapy advances have proportioned to AIDS patients a survival increase. At the same time, the permanence of the seropositive people in the nosocomial environment becomes common not only by the adverse reactions caused by this therapy, but also by several opportunistic diseases that take them into and out of hospital environment. During the hospital permanence, the patients expose their impaired immune system to the nosocomial virulent microorganisms, and acquire destructive nosocomial infections that sometimes can be lethal. Among several hospital syndromes described, little is known about infections in immunocompromised patients and how their immune system is able to determine the course of the infection. The objective of this study was to describe the major microorganisms involved in the nosocomial infections of HIV-1 seropositive patients associated with their immunological status. The survey was carried out with the Hospital Infection Control Service records, from University Hospital, Londrina, Paraná, Southern of Brazil, during the period from July 2003 to July 2004. From all the cases studied ( $\mathrm{n}=969), 24$ patients $(2.5 \%)$ had AIDS diagnosis and a half of them was women with the mean of $\mathrm{CD}^{+} \mathrm{T}$ cells counts of $158 / \mathrm{mm}^{3}$. The main topography of the infection was pulmonary (50.0\%) and the main isolated microorganisms were Staphylococcus aureus, Pseudomonas aeruginosa and Escherichia coli. A major incidence of infection was observed in patients with $\mathrm{CD}^{+} \mathrm{T}$ cells counts lower than $50 / \mathrm{mm}^{3}$. The study of the relationship between the impairment of the immune system and infectious agents could provide a better healthcare of people living with HIV/AIDS and advances into the nosocomial infection control systems.
\end{abstract}

Key-words: AIDS, CD4 ${ }^{+} \mathrm{T}$ cell counts, nosocomial infections, immunocompromised

\section{INTRODUCTION}

Nosocomial infections (NIs) are resulted from treatment in a hospital or hospital-like setting, but secondary to the patient's primary condition and constitute a problem of world-wide public health, that promote greater nosocomial permanency and an increase in the developing countries rates of mortality and morbidity $(4,8)$.

NIs are even more alarming in the $21^{\text {th }}$ century as antibiotic resistance spreads. Reasons why these infections are common include hospitals house large number of people who are sick and whose immune system are often in a weakened state; medical staff move from patient to patient provoking a way for pathogens spreading; many medical procedures bypass the body's natural protective barriers and the routine use of antimicrobial agents in hospital creates selection pressure for the emergence of resistant strains (8).

The most common NIs are of the urinary tract and various pneumonias $(6,8,32)$ and few studies have been reported about their occurrence in immunocompromised individuals.

Currently, the imunossupression is a state that is very common because the advances of science to increase survival

*Corresponding Author. Mailing address: Rua Maranhão 314 s1 71, Londrina, PR, CEP 86010-903, Brazil. Phone: 043 3322-7774 / 043 $9916-5317$.

E-mail: carolpanis@sercomtel.com.br 
in the extremities of age and the increase of the incidence of diseases that impair the immune system, such as neoplasia and the Acquired Immunodeficiency Syndrome (AIDS) $(3,23)$. AIDS is the advanced clinical phase of the infection caused by the human immunodeficiency virus types 1 (HIV-1) and 2 (HIV-2) (27). The progression of HIV-1 infection causes immunological dysfunctions that contribute either to the appearance of opportunist diseases or to the reactivation of latent infections.

The predominant immunological characteristic in the course of HIV-1 infection is the progressive depletion of $\mathrm{CD}^{+} \mathrm{T}$ helper type 1 subpopulation of lymphocytes $\left(\mathrm{CD} 4^{+} \mathrm{Th} 1\right)$ that changes the normal rate between $\mathrm{CD} 4^{+} \mathrm{T} / \mathrm{CD} 8^{+} \mathrm{T}$ lymphocytes and promotes the immunodeficiency (DIAS et al., 2003). The $\mathrm{CD} 4^{+} \mathrm{T}$ cell count has important role to the introduction of high active antiretroviral therapy (HAART) (13).

Barlett \& Gallant (1) revised the correlation between the appearance of complications of HIV-1 infection and $\mathrm{CD}^{+} \mathrm{T}$ cell counts from AIDS patients. However, the available data reported the acquired opportunist infections that occurred in the community, and little is known about the correlation between the number of these cells and the appearance of NIs and its causal pathogens. Although various studies described the different infections developed by HIV/AIDS patients during the nosocomial period and their etiological agents, the correlation between the pathogens and the compromising immunological status is still little explored.

The aim of this study was to describe the immunological profile and to characterize the etiological agents of NIs in HIV/ AIDS patients, in order to contribute for improvements in the nosocomial infection control and cares in these patients.

\section{MATERIALS AND METHODS}

A retrospective study was carried out involving all patients admitted at the University Hospital from Londrina, Paraná, Southern of Brazil, whose were registered NIs during the period from July 2003 through July 2004. Patients personal data, CD4 ${ }^{+} \mathrm{T}$ cell counts and the isolated microorganisms results were collected from notified data of the active researches of the Nosocomial Infections Control Center (CCIH) from this health service. This study was approved by the Research Ethics Committee of the Londrina State University. The variables investigated were age, gender, topography, $\mathrm{CD} 4^{+} \mathrm{T}$ cell counts, clinical evolution and microorganisms isolated from these patients.

\section{RESULTS}

The total number of registered NIs cases in the studied period was 969 (Table 1). Of them, 257 (26.52\%) occurred in patients admitted to the Newborn Intensive Therapy Unit, 158 $(16.30 \%)$ were patients admitted to the Intensive Treatment Unit I and $157(16.20 \%)$ were patients admitted to the Female Nursing
Table 1. Distribution of nosocomial infections registered in patients attended at University Hospital, Londrina, Paraná, Southern Brazil, from July 2003 to July 2004, according to nosocomial unit.

\begin{tabular}{lcc}
\hline \multicolumn{1}{c}{ Nosocomial Unit } & Case Number (n) & $\%$ \\
\hline Male Nursing Unit & 257 & 26.50 \\
Intensive Treatment Unit I & 158 & 16.30 \\
Female Nursing Unit & 157 & 16.21 \\
Newborn Intensive Treatment Unit & 81 & 8.36 \\
Emergency & 78 & 8.05 \\
Pediatric Unit & 68 & 7.02 \\
Intensive Treatment Unit II & 45 & 4.65 \\
Infectious Diseases Unit & 42 & 4.34 \\
Pediatric Intensive Treatment Unit & 24 & 2.48 \\
Intensive Care Unit & 22 & 2.28 \\
Maternity Unit & 20 & 2.07 \\
Dialysis Unit & 11 & 1.14 \\
Tisiology Unity & 5 & 0.5 \\
Pediatric Nursing & 1 & 0.1 \\
\hline TOTAL & $\mathbf{9 6 9}$ & $\mathbf{1 0 0 . 0}$ \\
\hline
\end{tabular}

Table 2. Distribution of nosocomial infections registered according to the gender of the patients attended at University Hospital, Londrina, Paraná, Southern Brazil, from July 2003 to July 2004.

\begin{tabular}{lcc}
\hline Gender & Number $(\mathrm{n})$ & $\%$ \\
\hline Male & 591 & 61.0 \\
Female & 276 & 28.5 \\
Newborn * & 102 & 10.5 \\
\hline TOTAL & $\mathbf{9 6 9}$ & $\mathbf{1 0 0 . 0}$ \\
\hline
\end{tabular}

* The gender was not registered in these cases.

Unit. The distribution of the cases, according to the gender, is presented in Table 2. Most of the cases occurred in male patients representing 591 cases $(61.0 \%)$.

Of the total 969 patients, 24 (2.5\%) had the AIDS diagnosis. The distribution of the NIs number among these patients according to the sex was of $50.0 \%$ and the age ranged from 0 to 78 years old, with the mean of 40.2 years old (Table 3 ).

The mean time of permanence in the hospital was of 36.16 days and 13 patients dead during this period. The mean $\mathrm{CD} 4^{+} \mathrm{T}$ cell count was 158.4 cells $/ \mathrm{mm}^{3}$ (Table 3 ). In relation to infection sites, the main topography was the lung $(50.0 \%)$, followed by infections in multiple sites (25.0\%), urinary tract infections (8.3\%) and bloodstream (8.3\%), as demonstrate the Table 3 and the 
Table 3. Distribution of nosocomial infections registered cases in HIV/AIDS patients attended at University Hospital, Londrina, Paraná, from July 2003 to July 2004, according to gender, age, nosocomial permanence, topography, isolated microorganism, CD4+ $\mathrm{T}$ cell counts and clinical evolution.

\begin{tabular}{|c|c|c|c|c|c|c|c|}
\hline Case & Gender & $\begin{array}{c}\text { Age } \\
\text { (years) }\end{array}$ & $\begin{array}{c}\text { Nosocomial } \\
\text { permanence } \\
\text { (days) }\end{array}$ & $\begin{array}{l}\text { Topography of } \\
\text { infection }\end{array}$ & $\begin{array}{c}\text { Isolated } \\
\text { Microorganism }\end{array}$ & $\begin{array}{l}\mathrm{CD} 4^{+} \mathrm{T} \\
\text { cell counts } \\
(\text { cell/mm3) }\end{array}$ & $\begin{array}{c}\text { Clinical } \\
\text { evolution } \\
\text { to death }\end{array}$ \\
\hline 1 & $\mathrm{~F}$ & 26 & 145 & Meningis & - & 15 & No \\
\hline 2 & $\mathrm{~F}$ & 27 & 21 & Urinary tract & E. coli & 38 & No \\
\hline 3 & $\mathrm{~F}$ & 65 & 22 & Lung & E. coli & 25 & Yes \\
\hline 4 & M & 40 & 06 & Lung & - & - & Yes \\
\hline 5 & $\mathrm{~F}$ & 36 & 36 & $\begin{array}{l}\text { Urinary tract } \\
\text { Bloodstream }\end{array}$ & $\begin{array}{c}\text { E. coli } \\
\text { S. aureus }{ }^{a}\end{array}$ & 13 & Yes \\
\hline 6 & $\mathrm{~F}$ & 38 & 82 & $\begin{array}{l}\text { Urinary tract } \\
\text { Bloodstream }\end{array}$ & $\begin{array}{l}\text { P. aeruginosa } \\
\text { S. aureus }\end{array}$ & 203 & Yes \\
\hline 7 & $\mathrm{~F}$ & 27 & 19 & Lung & - & 216 & No \\
\hline 8 & M & 60 & 17 & Lung & - & - & No \\
\hline 9 & M & 58 & 17 & $\begin{array}{l}\text { Urinary tract } \\
\text { Lung }\end{array}$ & $\begin{array}{l}\text { P. aeruginosa }{ }^{b} \\
\text { S. aureus }\end{array}$ & 32 & Yes \\
\hline 10 & $\mathrm{~F}$ & 35 & 66 & $\begin{array}{l}\text { Lung } \\
\text { Catheter }\end{array}$ & $\begin{array}{l}\text { S. aureus }{ }^{a} \\
\text { A. baumanii } \\
\text { S. aureus }\end{array}$ & 23 & Yes \\
\hline 11 & M & 35 & 08 & Lung & - & 313 & Yes \\
\hline 12 & M & 31 & 59 & $\begin{array}{c}\text { Urinary tract } \\
\text { Paranasal sinuses }\end{array}$ & E. faecalis & 91 & Yes \\
\hline 13 & M & 54 & 84 & Lung & $\begin{array}{l}\text { S. aureus } \\
\text { K. ozanae }\end{array}$ & 1 & Yes \\
\hline 14 & M & 48 & 27 & Urinary tract & P. aeruginosa ${ }^{c}$ & 416 & No \\
\hline 15 & $\mathrm{~F}$ & 26 & 6 & Lung & 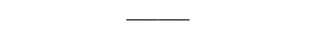 & 308 & No \\
\hline 16 & $\mathrm{~F}$ & 18 & 45 & Perithoneum & - & 336 & No \\
\hline 17 & M & 62 & 36 & Lung & - & 113 & No \\
\hline 18 & M & 44 & 39 & Lung & P. aeruginosa ${ }^{c}$ & 216 & No \\
\hline 19 & M & 54 & 42 & $\begin{array}{l}\text { Urinary tract } \\
\text { Catheter }\end{array}$ & $\begin{array}{l}\text { P. aeruginosa }{ }^{d} \\
\text { S. aureus }{ }^{a}\end{array}$ & 1 & Yes \\
\hline 20 & M & 40 & 18 & Bloodstream & K. pneumoniae & 802 & Yes \\
\hline 21 & $\mathrm{~F}$ & 28 & 21 & Lung & - & 300 & Yes \\
\hline 22 & M & 34 & 11 & Lung & - & 1 & Yes \\
\hline 23 & $\mathrm{~F}$ & 32 & 31 & Bloodstream & - & 19 & Yes \\
\hline 24 & $\mathrm{~F}$ & 47 & 10 & Lung & - & 3 & No \\
\hline$n=24$ & $\begin{array}{l}\mathrm{F}=12 \\
\mathrm{M}=12\end{array}$ & $\begin{array}{l}\text { Mean } \\
40.2\end{array}$ & $\begin{array}{c}\text { Mean } \\
36.2\end{array}$ & $\begin{array}{c}50.0 \% \text { lung } \\
25.0 \% \text { mixed } \\
8.3 \% \text { urinary tract } \\
4.1 \% \text { perithoneum } \\
4.1 \% \text { meningis } \\
8.3 \% \text { bloodstream }\end{array}$ & $\begin{array}{c}50.0 \% \text { of } \\
\text { infections had } \\
\text { an isolated } \\
\text { microorganism } \\
66.67 \% \text { of them } \\
\text { showed drug } \\
\text { resistance phenotype }\end{array}$ & $\begin{array}{c}158.4 \pm 40.3^{*} \\
(\mathrm{n}=22)\end{array}$ & $\begin{array}{c}50.4 \% \\
\text { dead }\end{array}$ \\
\hline
\end{tabular}

a oxacilina resistant strain (ORSA); $\mathbf{b}$ betalactamase producing strain; $\mathbf{c}$ carbapenase producing strain (CESP); $\mathbf{d}$ carbapenase producing strain and resistant to the polimixina; e extended spectrum betalactamase producing strain (ESBL); * average \pm standard deviation; $\mathrm{n}=$ total considered; $\mathrm{M}=$ male; $\mathrm{F}=$ female; $\_$; no data available. 
Fig. 1. Microorganisms were isolated from culture in $50.0 \%$ of the cases. Of them, $66.7 \%$ showed antimicrobial drug resistance. The major incidence of microorganisms in AIDS patients and clinical evolution to death was observed when the $\mathrm{CD} 4{ }^{+} \mathrm{T}$ cell counts were lower than 50 cells $/ \mathrm{mm}^{3}$ (Tables 4 and 5 , respectively). However, the differences were not significant (Fisher's Exact Test, $\mathrm{p} \cong 1.000$ and $\mathrm{p}=0.687$, respectively). The most frequent isolated microorganisms were Staphylococcus aureus (S. aureus) in $36.8 \%$ of cases, Pseudomonas aeruginosa (P. aeruginosa) in $26.3 \%$ of cases and Escherichia coli (E.coli) in $15.8 \%$ of cases (Fig. 2).

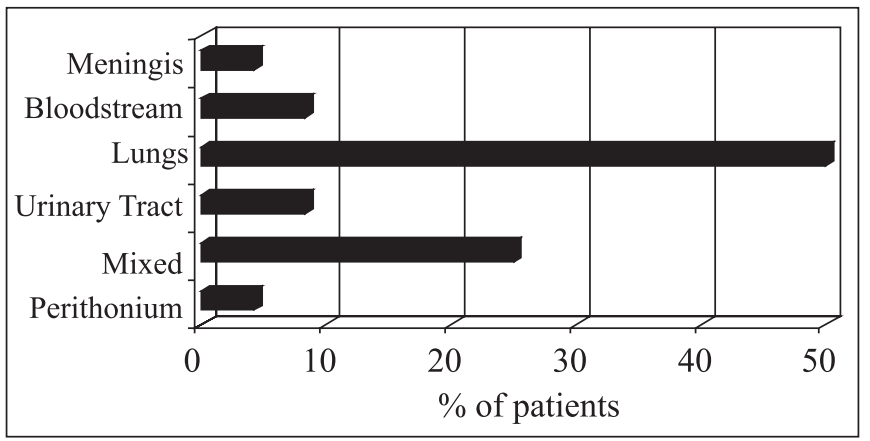

Figure 1. Distribution of the total registered cases according to the topography of the infection of HIV/AIDS patients attended at University Hospital, Londrina, Paraná, from July 2003 to July 2004.

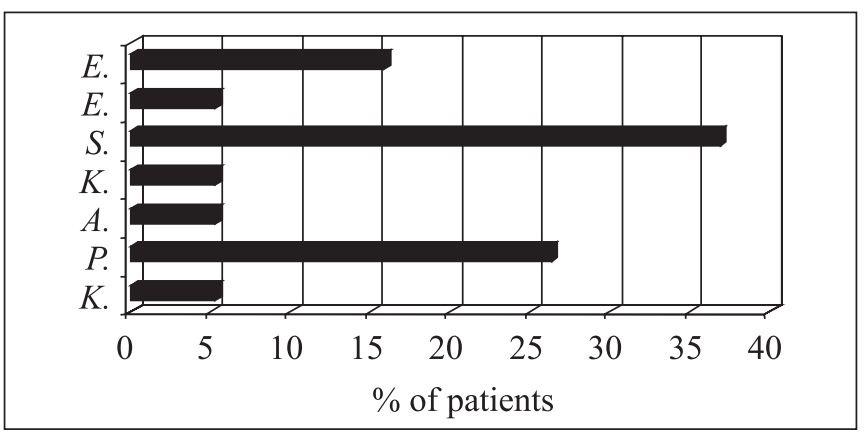

Figure 2. Major microorganisms isolated from biological samples from HIV/AIDS patients attended at University Hospital, Londrina, Paraná, from July 2003 to July 2004.

\section{DISCUSSION}

NIs are pointed as the major cause of morbidity and mortality in hospitalized patients. According to Center of Diseases Control, the NIs occurrence costs approximately US\$2,100,
Table 4. Distribution of HIV/AIDS patients attended at University Hospital, Londrina, Paraná, Southern Brazil, from July 2003 to July 2004, according to the isolation of microorganisms and $\mathrm{CD} 4^{+} \mathrm{T}$ cell counts.

\begin{tabular}{|c|c|c|c|}
\hline $\begin{array}{l}\mathrm{CD} 4^{+} \mathrm{T} \text { cell } \\
\text { counts } \\
\left(\text { cells } / \mathrm{mm}^{3}\right)\end{array}$ & $\begin{array}{l}\text { Patients with } \\
\text { isolated } \\
\text { microorganism } \\
\mathrm{n}(\%)\end{array}$ & $\begin{array}{c}\text { Patients with } \\
\text { out isolated } \\
\text { microorganisms } \\
\mathrm{n}(\%)\end{array}$ & $\begin{array}{l}\text { Total } \\
\mathrm{n}(\%)\end{array}$ \\
\hline$\geq 500$ & $1(8.3)$ & $0(0.0)$ & $1(4.5)$ \\
\hline$<500$ and $\geq 50$ & $5(41.7)$ & $5(50.0$ & $10(45.5)$ \\
\hline$<50$ & $6(50.0)$ & $5(50.0)$ & $11(50.0)$ \\
\hline Total & $12(54.5)$ & $10(45.5)$ & $22(100.0)$ \\
\hline
\end{tabular}

n: number of patients; \%: percentage, $p @ 1.000$ (Fisher’s Exact Test)

Table 5. Occurrence of death in HIV/AIDS patients attended at University Hospital, Londrina, Paraná, Southern Brazil, from July 2003 to July 2004, according to the isolation of microorganisms and $\mathrm{CD} 4^{+} \mathrm{T}$ cell counts.

\begin{tabular}{cccc}
\hline $\begin{array}{c}\mathrm{CD} 4^{+} \mathrm{T} \text { cell } \\
\text { counts } \\
\left(\text { cells } / \mathrm{mm}^{3}\right)\end{array}$ & $\begin{array}{c}\text { Death cases in } \\
\text { microorganism } \\
\text { presence } \\
\mathrm{n}(\%)\end{array}$ & $\begin{array}{c}\text { Death cases in } \\
\text { microorganisms } \\
\text { absence } \\
\mathrm{n}(\%)\end{array}$ & $\begin{array}{c}\text { Total } \\
\mathrm{n}(\%)\end{array}$ \\
\hline$\geq 500$ & $1(11.1)$ & $0(0.0)$ & $1(7.7)$ \\
$<500$ and $\geq 50$ & $2(22.2)$ & $2(50.0)$ & $4(30.8)$ \\
$<50$ & $6(66.7)$ & $2(50.0)$ & $8(61.5)$ \\
\hline Total & $9(69.2)$ & $4(30.8)$ & $13(100.0)$ \\
\hline
\end{tabular}

n: number of patients; \%: percentage, $\mathrm{p}=0.687$ (Fisher's Exact Test)

varying from US\$ 680 in bladder infections until US\$ 5,683 in respiratory tract infections.

The main described risk factors for HIV/AIDS patients to acquire NIs, beyond the immunossuppression state, are the length of stay in the hospital, insertion of urinary catheter, bloodstream access, multiple admissions to the hospital, number and duration of invasive procedures, use of prophylactic antimicrobials and malnutrition $(3,25)$. Colonization seems to play an important role in NIs among these immunocompromised patients $(16,25)$.

Amongst the NIs cases in HIV/AIDS patients evaluated in this study, a similar gender distribution was observed. Few reports in literature showed the distribution of these infections in AIDS patients considering parameters as gender, age or length of hospitalization. The gender was pointed as a risk factor for nosocomial Gram-positives infections in male (16), what can be observed in $57.1 \%$ of HIV-infected patients of this study. 
Studies carried out about NIs in HIV/AIDS patients $(9,24,26)$ reported the bloodstream as the main topography. In the present study, however, a low frequency of this site of infection was demonstrated $(8.3 \%)$ and can be related to the low sensitivity of the hemoculture, the major diagnosis method for bacteremia. The highest frequency in our study was the pulmonary topography, which is related as an important cause of treatable morbidity among HIV-1 patients (8). The infections related to the respiratory tract are pointed as the major NI syndrome (7), independently of the original disease and immunological status of the patients and can be related with the high number of invasive procedures in this topography, frequently used as the HIV-1 infection progresses (1). In a case-control study, Tumbarello and collaborators verified that the CD4+ T cells counting $<100 / \mathrm{mm}^{3}$ was a risk factor to the community and nosocomial acquired pneumonia. In our data, the distribution of this site of infection was $46.2 \%$ of the total number of patients with CD4+ T cell counting lower than $100 / \mathrm{mm}^{3}$, underscorsing the fact that the nosocomial acquired pneumonia can occurs at all CD4+ T cell counting (8).

All the HIV-1 infected patients enrolled in this study had AIDS diagnosis, the most advanced phase of the HIV-1 infection. The $\mathrm{CD}^{+} \mathrm{T}$ cell counts in these patients showed results that ranged from 1 to 802 cells $/ \mathrm{mm}^{3}$, with average of 158.4 cells $/ \mathrm{mm}^{3}$, and the majority of these patients showed values bellow of 400 cells $/ \mathrm{mm}^{3}$, as are expected in these patients in the phase of opportunist diseases or reactivation of latent infections $(1,3,9,25)$.

A reduction is observed in the evolution of $\mathrm{CD}^{+} \mathrm{T}$ cell counts throughout the years after the AIDS diagnosis and characterizes the last disease clinical phase with values bellow 200 cells $/ \mathrm{mm}^{3}$; in this phase occurs the development of opportunist disease, the reactivation of latent infections and other organic complications, as well it is considered an indicator of mortality (1). Many clinical and laboratory measures have been used to asses prognosis and disease progression in HIV1 infection. Previous studies showed that the single best predictor of progression to AIDS was the percentage or absolute number of circulating CD4+ T cells; further studies showed that plasma viral load was a better indicator of prognosis that CD4+ T cell. Currently, the combined measurement of plasma viral load and CD4+ $\mathrm{T}$ cell counts is useful to predict the disease progression (21).

The CD4+ T cell gradually declines over several years with a more accelerated decline 1.5-2 years before an AIDS-defining diagnosis. Late-stage of the disease is characterized by a CD4 + $T$ cell count $<200$ cells $/ \mathrm{mm}^{3}$ and the development of opportunist infections, selected tumors, wasting and neurologic complications (BARLETT et al., 2000). Thus, the results obtained in this study are in agreement with the literature. Prophylactic treatment for opportunistic infections is recommended when CD4+ T cell counting is lower than $200 / \mathrm{mm}^{3}$ (27).
The major microorganisms isolated were from the patients with CD4+ T cell $<500 / \mathrm{mm}^{3}$ which confirm the importance of this laboratory marker in the prognosis of HIV-1 infection. Considering that NIs also constitute in an opportunist disease for these patients, it is possible that exist a relation between $\mathrm{CD} 4^{+} \mathrm{T}$ cell counts and the incidence of NIs.

Major incidence of culture isolated microorganisms was observed in those patients that $\mathrm{CD} 4^{+} \mathrm{T}$ cell counts were bellow 500 cells $/ \mathrm{mm}^{3}$. The main microorganisms isolated were $S$. aureus, P. aeruginosa and E. coli (Table 4 and Fig. 2), in accordance with previous reports in the literature $(15,16,29)$.

S. aureus is described as a NI agent in HIV-1 patients (16) and is distinguished for its capacity in producing resistance mechanisms that difficult the antimicrobial drug therapy. The meticilin-resistant $S$. aureus (MRSA) appeared as a nosocomial agent at 1960's in countries of the Europe and 1976 in U.S.A. In Brazil, the meticilin is not used. Thus, the cited microorganisms as MRSA are tested against the oxacilina and so called oxacilinresistant (ORSA), since both antibiotics are equivalents.

Considering the microorganism strains isolated in this study, $85.0 \%$ presented oxacilin resistance, indicating the selective pressure exerted by the drug antimicrobial therapies on these agents. Gram - positive microorganisms are described as the main isolated agents in AIDS patients and showed drugresistance mechanisms $(19,24)$. HIV-infected patients frequently receive prophylactic antimicrobial therapy that can be a possible cause of drug-resistance in the described cases.

The transmission of the MRSA occurs mainly through the contaminated hands of the health professionals, since these microorganisms are able to survive for hours in the enviroment. The surfaces of the environment also can be a source of transmission $(15,16)$. The main risk factors for infection with MRSA include age, previous long time hospitalization, long hospital permanence, admission into intensive care units, chronic illness, previous antimicrobials drug therapy, manipulation for colonized professionals, and accomplishment of invasive procedures (15) that frequently occur in HIV-patients. MRSA $\mathrm{NI}$ in these patients is mainly related with the prolonged time of hospitalization, in agreement with the data showed in the present study (7).

Amongst the isolated Gram-negative microorganisms in this study, P. aeruginos $a$ and E. coli presented the highest frequency. This result is in agreement with the previous reports which affirmed that $P$. aeruginos $a$ is common in NIs and is pointed as an important agent of morbidity and mortality among HIV-1 patients because it can be fatal in the advanced stages of HIV-1 disease, specially when the $\mathrm{CD}^{+} \mathrm{T}$ cell counting is low $(11,22,31)$. Pseudomonas spp. are isolated from the studied patients and $80.0 \%$ of the isolated microorganisms showed some drug resistance mechanism, in accordance with previous studies which point multiresistant microorganisms as emergent problems for the NIs control, specially in HIV-1 infected patients (31). 
A microorganism is considered multiresistant when presents resistance at least three groups of antibiotics (16). The multiresistant microorganisms are more common in intensive treatment units than in other hospital units, due to the number of risk factors and intensive antimicrobial drugs use. The $P$. aeruginosa infections are considered of difficult treatment, and the most serious cases are described in weakness situations, compromised people or with reduced resistance (20). According with Table $3,60.0 \%$ of patients infected with Pseudomonas spp. had clinical evolution to death, that confirmed the severity of this infection in the studied cases.

Sorvillo and co-workers (31) described P. aeruginosa as one of the main etiologic agent of urinary tract infections in AIDS patients, as showed in $80.0 \%$ of the cases in the present study. This find can be due to the excess of invasive procedures in these patients and to its virulence factors, which are also associated with the infections in other sites in these patients $(20,22,28)$.

Another agent isolated with high frequency in this study was $E$. coli. This gram-negative microorganism integrates the group of the enterobacteria, common infectious agents acquired by the community as in the hospital environment and that are able to cause infections in the most diverse topographies. $E$. coli is characterized by presenting an ample drug resistance pattern due its capacity in degrading these drugs through the extended spectrum beta-lactamases (ESBL). The ESBL are enzymes that confer resistance to the antibiotic treatment with cefalosporines, constituting a sufficiently common hospital problem, since E. coli and Klebsiella spp. are common nosocomial pathogens (8). In this work, E. coli was isolated only from patients with $\mathrm{CD}^{+} \mathrm{T}$ cells counts lower than $50 / \mathrm{mm}^{3}$ and these microorganisms didn't show any antibiotic resistance, what can be related with the favoring environment created by the immune system weakness.

Fungal agents as Histoplasma capsulatum (14), Cryptococcus neoformans (35), Candida ssp. $(18,33)$ and mycobateria $(2,5,10,12,17)$ are also important causes of infection in HIV/AIDS patients. All these microorganisms are related both with multiple drug-resistance and the clinical evolution and can be potentially lethal (30). In this study, however, these microorganisms were not isolated in the cultures, a result that can be in part related to the difficult grown of these agents in the usual culture media which determines the low sensitivity for laboratorial diagnosis.

High mortality rate was observed in the HIV-1 infected patients of this study and the disease progression to death was observed in $45.8 \%$ of them. The association of the mortality with the NIs and with the CD4+ T cell was not observed, probably, because of the limited number of HIV-infected patients included in this study. The mortality rate observed could not be associated only to the NIs, since these patients were at risk for other common non-nosocomial diseases such as the reactivation of latent infections caused by the deterioration of the immune system and HIV disease progression.

\section{CONCLUSION}

The HIV infection has a complex and heterogeneous clinical course and the ability to control the infection and the disease progression depends of the balance between host and viral factors. With the deterioration of the immune system and HIV disease progression, revealed by the $\mathrm{CD} 4+\mathrm{T}$ cell counts, the AIDS patients are at an increased risk for NIs that contribute to the morbidity, to the significant increase of the length of hospitalization, and to the mortality of them. In this way, the results of nosocomial pathogens characterization and its relation with the immune status revealed by the CD4+ $\mathrm{T}$ cell counts in HIV/AIDS patients could contribute to advances in the hospital cares, to the improvement of the life quality of these patients and costs reduction for the health institutions.

\section{ACKNOWLEDGEMENTS}

We are grateful to Altair R. P. de Paula for help with data collecting.

\section{RESUMO}

\section{Infeç̧ões hospitalares em pacientes infectados com HIV-1 e com AIDS: principais microrganismos e perfil imunológico}

Avanços na terapia anti-retroviral têm proporcionado aos pacientes com AIDS um aumento na sobrevida. Ao mesmo tempo, a permanência de pacientes soropositivos no ambiente nosocomial torna-se comum não só pelos efeitos colaterais desta terapia, mas também pelas diversas doenças oportunistas que acometem estes indivíduos dentro e fora do ambiente hospitalar. Durante o período de internação, a fragilidade do sistema imunológico é exposta à virulência da microbiota nosocomial, adquirindo infecções hospitalares graves e muitas vezes fatais. Dentre as diversas síndromes de infecções hospitalares descritas, pouco se sabe sobre estas infecções em pacientes imunocomprometidos e sobre como o estado imunológico é capaz de determinar o curso destas infecções. Este trabalho teve como objetivo determinar os principais microrganismos envolvidos nas infecções hospitalares de pacientes soropositivos para a infecção pelo HIV-1 e descrever a associação com seu perfil imunológico. Realizou-se análise de dados de notificações do Serviço de Controle de Infecção Hospitalar do Hospital Universitário, Londrina, Paraná, na região sul do Brasil, no período de julho de 2003 a julho de 2004. Do total de casos estudados ( $\mathrm{n}=969), 24$ pacientes $(2,5 \%)$ tinham o diagnóstico de AIDS, sendo metade do gênero feminino, com contagem média 
de células T CD4 $4^{+}$de $158,4 / \mathrm{mm}^{3}$. A principal topografia foi o sítio pulmonar (50,0\%), sendo Staphylococcus aureus, Pseudomonas aeruginosa e Escherichia coli os principais microrganismos isolados. Observou-se maior incidência de infecção em pacientes com contagem de células T CD4 $4^{+}$menor que $50 / \mathrm{mm}^{3}$. O estudo da relação entre sistema imunológico e microrganismos causadores de infecções poderá contribuir para melhorias nos cuidados de pacientes com AIDS e avanços nos sistemas de controle de infecção hospitalar.

Palavras-chave: AIDS, contagem de células TCD4 $4^{+}$, infecções nosocomiais, imunocomprometidos.

\section{REFERENCES}

1. Barlett, J.G.; Gallant, J.E. (2000). 2000-2001 Medical management of HIV infection. Port City Press, Baltimore.

2. Bennet, C.L.; Schwartz, D.N.; Parada, J.P.; Sipler, A.M.; Chmiel, J.S.; Dehohitz, J.A.; Goetz, M.B.; Weinstein, R.A. (2000). Delays in tuberculosis isolation and suspicion among persons hospitalized with HIV-related pneumonia. Chest 117, 110-116.

3. Cavalcante, N.J.F. (2000). Infecções em pacientes imunologicamente comprometidos. In: Fernandes, A.T.; Fernandes, M.O.V.; RibeiroFilho, N. Infecção hospitalar e suas interfaces na área da saúde. Atheneu, São Paulo.

4. Centers for Disease Control and Prevention (1992). Public health focus: surveillance, prevention and control of nosocomial infections. MMWR, 41, 783-787.

5. Chimzizi, R.B.; Harries, A.D.; Hargreaves, N.; Kwanjana, J.H.; Salaniponi, F.M. (2001). Care of HIV complications in patients receiving anti-tuberculosis treatment in hospitals in Malawi. Int. J. Tuberc. Lung Dis., 5 (10), 979-981.

6. Dias Neto, J.A.; Silva, L.D.M.; Tiraboschi, R.B.; Domingos, A.L.A.; Suiad, H.J.; Tucci Junior, S.; Cologna, A.J. (2003). Prevalence and bacterial susceptibility of hospital acquired urinary tract infection. Acta Cir. Bras. 18, 36-38.

7. Fernandes, A.T.; Fernandes, M.O.V. (2000). Vigilância epidemiológica das infecções hospitalares. In: Fernandes, A.T.; Fernandes, M.O.V.; Ribeiro-Filho, N. Infecção hospitalar e suas interfaces na área da saúde. Atheneu, São Paulo.

8. Eulalia-Valencia, M.; Enriques, A.; Soriano, V.; Moreno, V.; Laguna, F.; Gonzalez-Lahoz, J. (1997). Nosocomial infection with meticilinresistant Staphylococcus aureus in 14 human immunodeficiency vírus infected patients. Med. Clin (Barc)., 109 (7), 261-263.

9. Frank, U.; Daschner, F.D.; Schulgen, G.; Mills, J. (1997). Incidence and epidemiology of nosocomial infections in patients infected with human immunodeficiency virus. Clin. Infect. Dis., 25, 318-320.

10. Franzetti, F.; Goi, A.; Iemoli, E.; Meraviglia, P.; Mainini, F.; Quirino, T.; Degli-Esposti, A.; Degl'Innocenti, M.; Grassini, A.; Nardi, G.; Cargnel, A. (1999). Outcome of multidrug-resistant tuberculosis in human immunodeficiency vírus-infected patients. Clin. Infect. Dis., 29 (3), 553-560.

11. Freitas, A.L.; Barth, A.L. (2004). Typing of Pseudomonas aeruginosa from hospitalized patients: a comparison of susceptibility and biochemical profiles with genotype. Braz. J. Med. Biol. Res., 37, 7782 .

12. Hannan, M.M.; Azadian, B.S.; Gazzard, B.G.; Hawkins, D.A.; Hoffman, P.N. (2000). Hospital infection control in an era of HIV infection and multi-drug resistant tuberculosis. J. Hosp. Infect., 44 (1), 5-11.

13. Ho, C.F.; Lee, S.S.; Wong, K.H.; Cheng, L.S.; Lam, M.Y. (2007). Setting a minimum threshold CD4 count for initiation of highly active antiretroviral therapy in HIV-infected patients. HIV Med. 3, $181-185$.

14. Hung, C.C.; Hsuesh, P.R.; Hsieh, S.M.; Liu, C.J.; Chen, M.Y.; Luh, K.T. (1998). Bacteremia and fungemia in patients with advanced human immunodeficiency virus (HIV) infection in Taiwan. J. Formos. Med. Assoc., 97 (10), 690-697.

15. Jaimes, E.C.; Espinosa-de-los-Monteros, E.L.; Ávila-Beltran, R. (2002). Epidemiology of drug resistance: the case of Staphylococcus aureus and coagulase-negative staphylococci infections. Rev. Salud Pub. México, 44, 108-112.

16. Korn, G.P.; Martino, M.D.V.; Mimica, I.M.; Mimica, L.J; Chiavone, P.A.; Musolino, L.R.S. (2001). High frequency of colonization and absence of identifiable risk factors for methicillin-resistant Staphylococcus aureus (MRSA) in intensive care units in Brazil. Braz. J. Infect. Dis. 5, 1-7.

17. Laing, R.B. (1999). Nosocomial infections in patients with HIV disease. J. Hosp. Infect., 43 (3), 179-85.

18. Launay, O.; Lortholary, O.; Bouges-Michel, C.; Jarrouse, B.; Bentata, M.; Guillevin, L. (1998). Candidemia: a nosocomial complication in adults with late-stage AIDS. Clin. Infect. Dis., 26 (5), 1134-1141.

19. Loureiro, M.M.; Moraes, B.A.; Quadra, M.R.R.; Pinheiro, G.S.; Asensi, M.D. (2002). Study of multi-drug resistant microorganisms isolated from blood cultures of hospitalizated newborns in Rio de Janeiro city, Brazil. Braz. J. Microbiol., 33, 73-78.

20. Manfredi, R.; Nanetti, A.; Ferri, M.; Chiodo, F. (2000). Pseudomonas spp. complications in patients with HIV disease: an eight-year clinical and microbiological survey. Eur. J. Epidemiol., 16 (2), 111-8.

21. Mellors, J.W.; Munoz, A.; Giorgi, J.; Margolick, B.; Tassoni, C.J.; Gupta, P.; Kingsley, L.A.; Todd, J.A.; Saah, A.J.; Detels, R.; Phair, J.P.; Rinaldo, C.R. (1997). Plasma viral load and CD4+ lymphocytes as prognostic markers of HIV-1 infection. Ann Intern Med., 126 (12), 946-954.

22. Meynard, J.L.; Barbut, F.; Guiguet, M.; Batisse, D.; Lalande, V.; Lesage, D.; Guiard-Schmid, J.B.; Petit, J.C.; Frottier, J.; Meyohas, M.C. (1999) Pseudomonas aeruginosa infection in human immunodeficiency virus infected patients. J. Infect., 38 (3), 176-81.

23. Nucci, M.L.M.; Pulcheri, W.A. (1998). A. Infecções no paciente imunodeprimido. In: Schechter, M.; Marangoni, D.V.M. Doenças infecciosas: conduta diagnóstica e terapêutica. Guanabara Koogan, Rio de Janeiro.

24. Padovezze, M.C.; Trabasso, P.; Branchini, M.L. (2002). Nosocomial infections among HIV-positives and HIV-negatives patients in a Brazilian Infectious Disease Unit. Am. J. Infect. Control 6, 346350. Available at: http://www.ncbi.nml.nih.gov. Accessed 12 may 2007.

25. Petrosillo, N.; Pagani, L.; Ippolito, G. (2003). Nosocomial infections in HIV-positive patients: an overview. Infection, 2, 28-34. Available at: http://www.ncbi.nml.nih.gov. Accessed 12 may 2007.

26. Petrosillo, N.; Viale, P.; Nicastri, E.; Arici, C.; Bombana, E.; Casella, A.; Cristini, F.; De Gennaro, M.; Dodi, F.; Gabbuti, A.; Gattuso, G.; Irato, L.; Maggi, P.; Pallavicini, F.; Pan, A.; Pantaleoni, M.; Ippolito, G. (2002). Nosocomial bloodstream infections among human immunodeficiency virus-infected patients: incidence and risk factors Clin. Infect. Dis., 34, 677-685.

27. Rachid, M.; Schechter, M. (2003). Manual de HIV/AIDS. Revinter, Rio de Janeiro.

28. Salavert, L.S.; Navarro-Ibánez, V.; Roig-Rico, P.; Bretón-Martinez, J.R.; Ponz-Diez, F.; Lopez-Aldeguer, J.; Gobernado-Serrano, M. (1996). Pseudomonas aeruginosa bacteremia in patients with HIV infection: clinic-epidemiologic study of 17 episodes. Rev. Clin. Esp. 196 (10), 684-691.

29. Silva, H.A.; Abdallah, V.O.S.; Carneiro, C.L.; Gontijo-Filho, P.P. (2003). Infection and colonization by Staphylococcus aureus in a high risk nursery of a Brazilian teaching hospital. Bras. J. Infect. Dis. 7, 381-386. 
30. Singh, L. (2003). Treatment of opportunistic mycoses: how long is long enough? Lancet Infect. Dis. 3 (11), 703-708.

31. Sorvillo, F.; Beall, G.; Turner, P.A.; Beer, V.L.; Kovacs, A.A.; Kerndt, P.R. (2001). Incidence and determinants of Pseudomonas aeruginosa infection among persons with HIV: association with hospital exposure. Am. J. Infect. Control, 29 (2), 79-84.

32. Stam, A.M.N. (2003). Bacteriúria assintomática: perfil clínicoepidemiológico. Rev. Bras. Med., 60, 185-190.

33. Tortorano, A.M.; Caspani, L.; Rigoni, A.L.; Biraghi, E.; Sicignano, A.; Viviani, M.A. (2004). Candidosis in the intensive care unit: a 20-year survey. J. Hosp. Infect., 57 (1), 8-13.
34. Tumbarello, M.; Tacconelli, E.; de Gaetano, K. (1998). Bacterial pneumonia in HIV-infected patients: analysis of risk factors and prognostic indicators. J. Acquir. Immune Def. Syndr. Hum. Retrovirol., 18 (1), 39-45.

35. Walsh, T.J.; Groll, A.H. (1999). Emerging fungal pathogens: involving challenges to immunocompromised patients for the twenty-first century. Transpl. Infect. Dis., 1 (4), 247-261. 